\title{
ACETYLATION OF AMINES : ENVIRONMENTALLY BENIGN METHOD
}

\author{
D. Panhekar a, S. Satpute b, A. Kalambe b \\ a Department of Chemistry, Dr Ambedkar College, Deeksha Bhoomi, \\ Nagpur, India, 440010 \\ b Department of Chemistry, Institute of Science, Nagpur, India, 440001 \\ Email: deepa.panhekar@gmail.com, shridharsatpute@gmail.com
}

\begin{abstract}
An efficient catalytic procedure for acetylation of amines into their corresponding acetylated products in good yields using acetyl chloride in the presence of fly ash catalyst has been described. The catalysts were found to be stable and were recycled several times without significant loss of activity under microwave irradiation in solventfree conditions.
\end{abstract}

Keywords: Acetylation, amines, microwave irradiation.

\section{Introduction}

Selective protection of amines is one of the most desirable transformations since it provides an efficient and inexpensive means of amino groups in a multistep synthetic process ${ }^{1}$. Acetic anhydride is commonly used reagent for acetylation of anilines. This reagent bears certain disadvantages ${ }^{2}$. In addition acetylation of amines has been carried out by using ethyl acetate ${ }^{3}$, ammonium acetate in acetic acid ${ }^{4}$, acetic acid in presence of $\mathrm{Fe}$ (III)-montmorillonite catalyst ${ }^{5}$ and acetic acid as acetylating agent under microwave irradiation ${ }^{6}$. Few methods of acetylation of amines are known using acetyl chloride of which most common is the use of acetyl chloride in pyridine ${ }^{7}$. Acetyl chloride has also been used in combination with some fairly exotic reagents such as $\mathrm{ZrOCl}_{2} \cdot 8 \mathrm{H}_{2} \mathrm{O}^{8}$, zinc dust ${ }^{9}$ and thermally decomposed Ni-Fe-hydrotalcite. ${ }^{10}$

Several types of substances such as acids, bases, clays, enzymes, ionic liquids and supercritical solvents have been employed to catalyze reactions. This is due to problems associated with prevailing catalysts like hazardous nature, high cost, tedious work up, difficult to handle, 
requirement of large quantities of organic solvents during and after the reaction and above all, their detrimental effects on environment ${ }^{11}$. In an attempt to overcome some of the deficiencies of catalysts used in organic synthesis, development of green procedures using heterogeneous catalysts under solvent-free conditions has aroused great interest in recent years ${ }^{12}$.

Fly ash is the solid waste residue produced from coal, oil, and biomass combustion. In the past few decades, more and more research has been devoted to explore the applications of fly ash in heterogeneous catalysis. It is a silico-aluminate material consisting of $\mathrm{SiO}_{2}, \mathrm{Al}_{2} \mathrm{O}_{3}$, and $\mathrm{Fe}_{2} \mathrm{O}_{3}$ as the major constituents and varying amount of $\mathrm{CaO}, \mathrm{MgO}, \mathrm{SO}_{3}-$ with unburned carbon. Besides these, some minor elements such as Hg, As, $\mathrm{Ge}, \mathrm{Ga}$, and traces of heavy metals (Cr, $\mathrm{Co}, \mathrm{Cu}, \mathrm{Pb}, \mathrm{Mn}, \mathrm{Ni}, \mathrm{Zn}$ ) \& other rare earth metals may also be present in fly ash ${ }^{13}$. The catalytic role of activated fly ash for different reactions such as oxidation ${ }^{14-15}$. chlorination 16 and condensation of short chain olefins ${ }^{17}$ is well documented in the literature. Fly ash was also used as solid support in the synthesis of 2-mercaptobenzothiazole derivatives under microwave irradiation ${ }^{18}$. Solvent free alkylation and acetylation of thymol and geraniol using fly ash as solid support is reported ${ }^{19}$. Recently, solid acid catalyst synthesized from fly ash has been used as a catalyst for acylation of salicylic acid under thermal conditions ${ }^{20}$. Herein we attempted microwave assisted acetylations of amines substrates in presence of fly ash.

\section{Materials and Methods}

Fly ash was obtained from Khaparkheda power plant, District Nagpur, Maharashtra state, India. The collected fly ash has the following composition: $\mathrm{SiO}_{2}, 50-54 ; \mathrm{Al}_{2} \mathrm{O}_{3}, 22-25 ; \mathrm{Fe}_{2} \mathrm{O}_{3}, 2-5 ; \mathrm{MgO}, 0.5-2.5$ and others $\left.\left(\mathrm{MnO}_{2}, \mathrm{CaO}, \mathrm{P}_{2} \mathrm{O}_{5}, \mathrm{TiO}_{2}, \mathrm{SO}_{3-}, \mathrm{Na}_{2} \mathrm{O}, \mathrm{K}_{2} \mathrm{O}\right), 0.002-2.5 \%\right)$. The irradiation with $300 \mathrm{~W}$ in the MW (Model MO9621, $2450 \mathrm{MHz}, 900 \mathrm{~W}$ ) 
was employed. Fly ash was riddled in a sieve to remove any coarser and foreign particles. The particle size distribution was found to be between 40-60um. The acetylations were carried out with the substrate to catalyst ratio as 10:1. The catalyst used in the reaction mixture was thermally stabilized by calcining at $600{ }^{\circ} \mathrm{C}$ for $6 \mathrm{~h}$ without any agitation and was recovered by filtration and regenerated for next cycle.

\section{Experimental Section}

Acetylation of various amines as shown in Scheme I have been performed by mixing amines substrate $(1 \mathrm{mmol})$, acetyl choride $(1 \mathrm{mmol}) \&$ fly ash in a $25 \mathrm{~mL}$ vial. The reaction mixture was irradiated in a microwave oven at $300 \mathrm{~W}$ for specified time as mentioned in the Table 1 . The reactions were monitored on TLC by comparison with authentic samples. Melting points were taken in open capillaries using paraffin baths and are uncorrected. The catalyst was activated at $600{ }^{\circ} \mathrm{C}$ in static air prior to the reaction for $6 \mathrm{~h}$. The crude product was subjected to silica gel column chromatography using 5\% EtOAc in light petroleum ether as eluent to get corresponding acetylated product in 78-92 \% yields (Table 1). The structure of the product was confirmed by $1 \mathrm{H} N M R, I R$ and by comparison with the authentic samples obtained commercially or prepared by reported methods.

\section{Synthesis of N-phenylacetamide (Table No 1, Entry 1)}

To a mixture of substrate $(1 \mathrm{mmol}) \&$ acetyl chloride $(1 \mathrm{mmol})$ in a $25 \mathrm{~mL}$ vial, activated fly ash (amine to catalyst weight ratio 10:1) was added. The reaction mixture was stirred properly with the help of a glass rod (<1min.) and then irradiated in a microwave oven at $300 \mathrm{~W}$. The progress of the reaction was monitored by TLC. The catalyst was removed by filtration and the reaction mass was added in chilled water to get the crude product. The crude product was subjected to silica gel column chromatography using 5\% EtOAc in light petroleum ether as eluent to 
get $\mathrm{N}$ - phenylacetamide (90\%). ${ }^{1} \mathrm{H}$ NMR (300 MHz, CDC13) $\delta 2.19$ (s, 3H), 7.16-7.11 (m, 1H), 7.28(s, 1H), 7.36-7.30 (m, 2H), 7.55-7.52 (m, 2H). IR $\left(\mathrm{cm}^{-1}\right)$ : 3293, 1662, 1598, 1557, 1500, 1431, 1368, 1325, 1262, 1040, $1012,962,906,750$.<smiles>Nc1ccccc1</smiles><smiles>CCOCCOC(=O)COC(C)=O</smiles><smiles>CC(=O)Nc1ccccc1</smiles>

Scheme I: Solvent free acetylation of aromatic amines

Table 1 : Microwave irradiated acetylation of aromatic amines under solvent free conditions

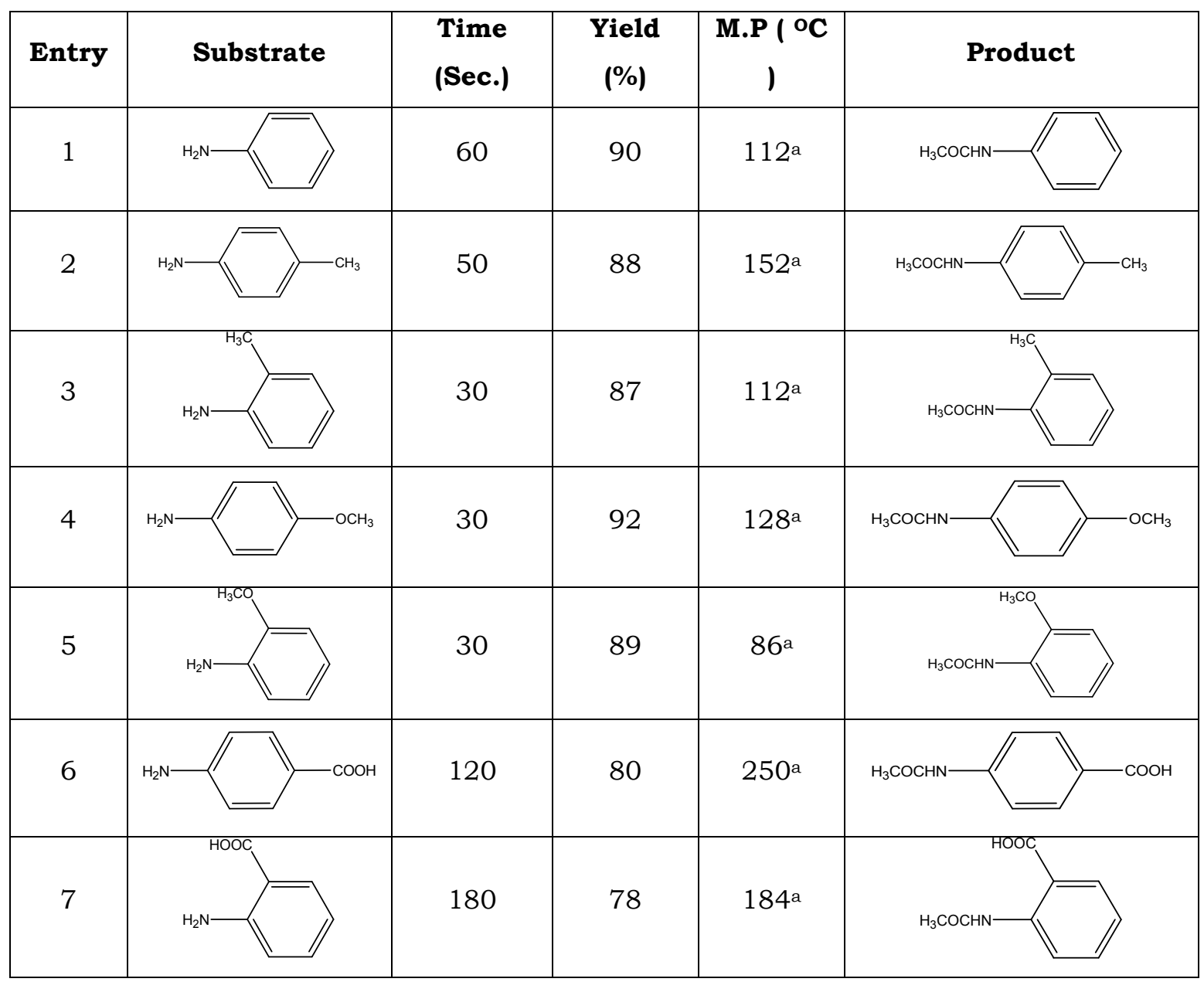


International Journal of Researches in

January 2014

ISSN No. (Online) Biosciences, Agriculture \& Technology

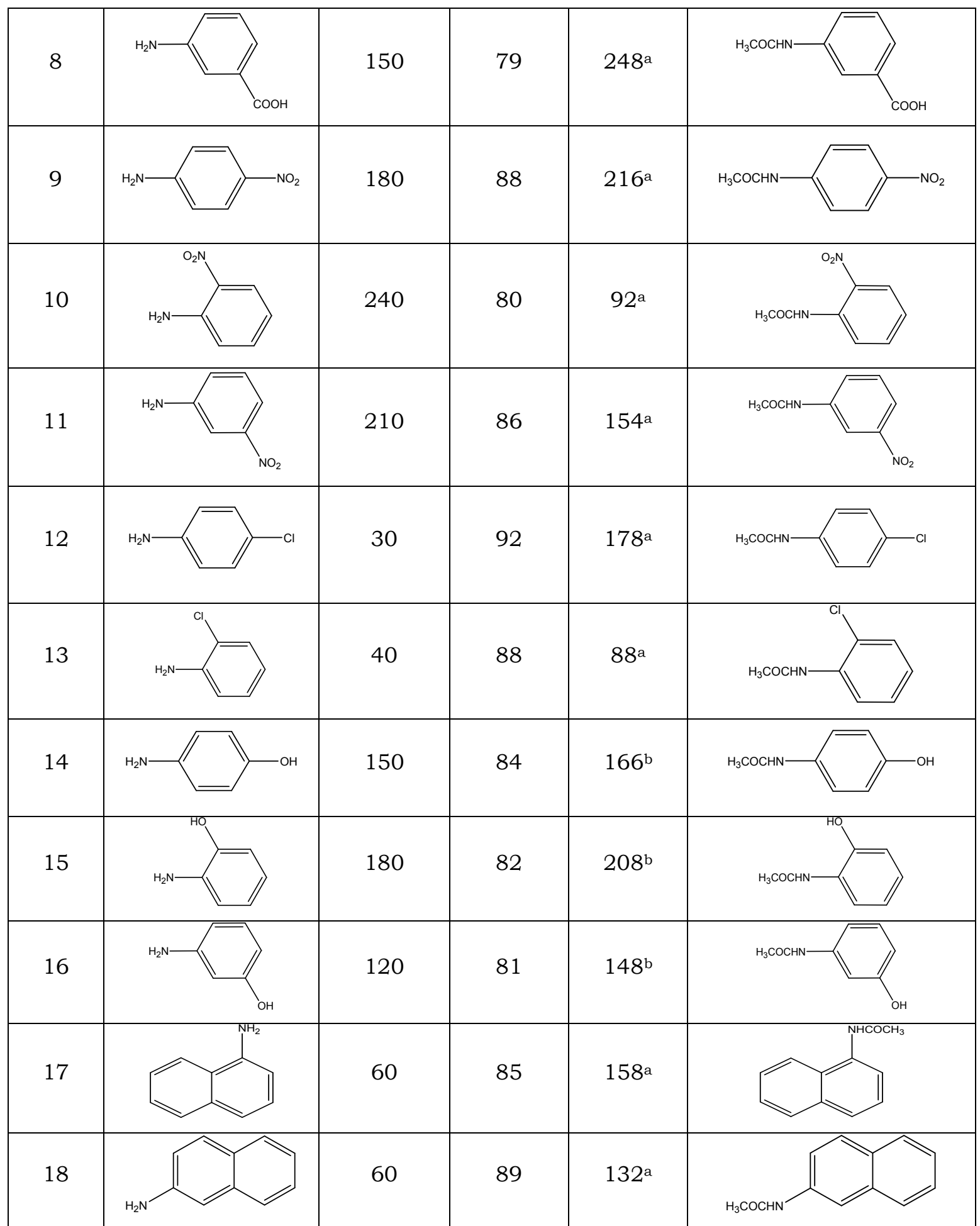

a: See Ref. No. 21, b: See Ref. No. 22 


\section{Results and Discussion}

Fly ash catalysed acetylations of amine compounds under microwave irradiation have been carried out and the results in Table 1 suggest generality of this method and the efficiency

of fly ash as a catalyst. The results also indicate the reduction of reaction time as compared to acetylation reaction conducted under thermal conditions $^{20}$. We have examined the recovery and reuse of the activated fly ash in the acetylation of aniline to get $\mathrm{N}$-phenylacetamide and found that the yields of the products in the second and third use of the catalyst were almost

same as that in the first run. In every case, fly ash catalyst was recovered by filtration, washing with acetone and drying in oven at $110{ }^{\circ} \mathrm{C}$ for $1 \mathrm{~h}$.

\section{Conclusion}

In conclusion, we have demonstrated an efficient and simple alternative for the acetylation reactions of amines using microwave irradiation under solvent free conditions in presence of fly ash. The process offered a dramatic reduction of reaction time. The attractive features of this process are the mild reaction conditions, high conversions, cleaner reaction profiles, operational simplicity and use of an easily and abundantly available fly ash, an industrial waste pollutant as a recyclable catalyst.

\section{Acknowledgements}

We thank Sophisticated Analytical Instrumental Facility (SAIF), Punjab University, Chandigarh, India for the spectral analysis. 


\section{References}

Green, and T.W.; Wuts, (1991), P.G.M. Protective Groups in Organic Synthesis, 3rd ed.; Wiley: New York.

Katritzky, 2000 , A. R.; He, H. -Y.; Suzuki, K. J. Org. Chem., 65, 8210.

Heravi M M, Bakhtiari K, Javadi N M, Oskooie H A, and Bamoharram F F , (2007), Monatshefte für Chemie 138, 445.

Prasad H S, Srinivasa G R, and Gouda D C (2005) Synth. Commun. 35 1189

Choudary B M, Bhaskar V, Lakshmi Kantam M, Rao K K, and Raghavan K V, (2001), Catal. Lett.74 20715.

a) Bahmachari G, Laskar S, and Sarkar S (2010) Ind. J. Chem. 49B 1274

b) Krishna Mohan K V V, Narendar N,and Kulkarni S J, (2006) Green Chem. 8, 368.

Olson V R, (2003), Feldman H B 1937 J. Am. Chem. Soc. 59.

Ghosh R, Maiti S,and Chakraborty A (2005) Tetrahedron Lett. 46147.

Pasha M A, Reddy M B M,and Manjula K (2010), Eur. J. Chem. 1385.

Choudhary V R, Dumbre D K 2011 Catal. Commun. 12, 1351.

Grieve M (1931) 'A Modern Herbal', Penguin Books, Bonner J, Varner JE (1965) 'Plant Biochemistry', Academic Press, Miller LP (1973) Phytochemistrys vol. I \& II', Van Norstrand Reinhold.

Sakakura, A.; Kawajiri, K.; Ohkubo, T.; Kosugi, and Y.; Ishihara, (2007), K. J. Am. Chem. Soc., 129, 14775-14779.

Kumar K. K. S, and Mehrotra S. P, (2007), Resour. Conserve. Recycle, $52,157-179$. 
Mallik D, and Choudhari S. K, Wat. (1999), Res., 33, 585-590.

Kastner J. R, Das, and Buquoi, (2003), Q; Melear N. D. Environ. Sci. Technol., 37, $2568-2574$.

Leer E. W. B. D, Lexmond R. J, and Zeeuw M. A. D, Chemosphere, (1989), 19, $1141-1152$.

Jarmohamed W, and Mulder P, Chemosphere,(1994), 29, 1911-1917.

Narkhede H. P, More U. B, Dalas D. S, Pawar N. S, More D. H, and Mahulikar P. P, (2007), Synthetic Comm., 37, 573-577.

Mahulikar P. P, J. (2006 ) Sci. Indus. Res., 65, 817-820.

Khatri C, Rani A, and A. Fuel (2008), 87, 2886-2892.

Furniss B S, Hannaford A J, Smith P W G and Tatchell A R, (1991) Vogel's Test book of practical Organic Chemistry, $5^{\text {th }}$ edn., 1370.

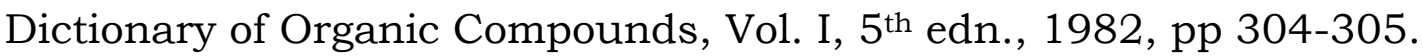

